\title{
Sowing time and nitrogen application methods impact on production traits of Kalonji (Nigella sativa L.)
}

\author{
Abid Mehmood, Khalid Naveed, Kamran Azeem*, Ayub Khan, Naushad \\ Ali and Shah Masaud Khan \\ Department of Agricultural Sciences, University of Haripur, Haripur-Pakistan \\ *Corresponding author's email: azeemmkd@gmail.com \\ Citation \\ Abid Mehmood, Khalid Naveed, Kamran Azeem, Ayub Khan, Naushad Ali and Shah Masaud Khan. Sowing time \\ and nitrogen application methods impact on production traits of Kalonji (Nigella sativa L.). Pure and Applied \\ Biology. Vol. 7, Issue 2, pp476-485. http://dx.doi.org/10.19045/bspab.2018.70060
}

\begin{tabular}{llll}
\hline \hline Received: 03/01/2018 & Revised: 15/03/2018 & Accepted: 16/03/2018 & Online First: 14/04/2018 \\
\hline \hline
\end{tabular}

\section{Abstract}

The establishment of Kalonji crop in climatic condition of District Haripur was studied for high quality and production through sowing time and nitrogen application methods. This study was carried out during Rabi 2016-17 at Agricultural Research Farm University of Haripur, KPK. The study was arranged in RCBD split plot arrangement having six sowing times as main plot while three nitrogen application methods were kept in subplots replicated thrice. Sowing time and nitrogen application methods significantly influenced plant height at $1^{\text {st }}$ flower initiation, plant height at maturity, days to maturity, number of capsules plant ${ }^{-1}$, number of seeds capsule ${ }^{-1}, 1000-$ grains weight, grain yield and fixed oil content however, essential oil content were nonsignificantly affected by application methods. Crop sown on $10^{\text {th }}$ November and nitrogen application methods 50\% during sowing, 25\% 60 DAS and remaining 25\% 90 DAS as foliar application increases the quality and production traits of Kalonji in agro-climatic conditions of District Haripur.

Keywords: Days after sowing; Kalonji; Nitrogen application methods; Sowing time

\section{Introduction}

Spices are consumed and appreciated for their unique flavor and aroma. They have entered the agricultural productivity around 6000 B.C though their presence was recorded in Neolithic sites even earlier [1]. Among the seed spices grown, black cumin (Kalonji) is considered as a miraculous spice having very important medicinal values apart from its intrinsic flavor [2]. It is also appreciated as magical herb for its ability to treat allergies, asthma, and immune disorders [3]. One of the most expansively studied plants, as a result of the growing interest in naturally occurring compounds with anti-cancer potential, is Nigella sativa. L also known as Black Seed, Black Cumin or Kalonji [4].

Kalonji is a field crop that belongs to Ranunculaceae, the butter cup family. The seeds or grains resembling onion seed are used both as spice and medicine [5]. The crop is known by many common names viz. Kalonji, black-caraway, fennel-flower, nigella, nutmeg-flower and roman-coriander [6]. In religion Islam, it is considered as one of the supreme forms of healing medicine 
available. The Prophet Muhammad (S.A.W) once stated that Kalonji can cure every disease except death [7]. Hence, it is appropriately known as seed of blessing (habbatul barakah) [8].

The crop is presently cultivated in parts of Asia, Africa, Europe and America. The major producing countries are India, Sri Lanka, Bangladesh, Afghanistan, Egypt, Iran, Iraq, Syria, Turkey and Ethiopia [9]. The crop productivity in India was reported to be between $300-500 \mathrm{~kg} \mathrm{ha}^{-1}$. However, little information is yet available about the crop's adoptability and productivity in the agroclimatic conditions of Pakistan [10]. Of all management aspects of growing a crop, sowing time is probably mostly subject to variation because of the very great differences in the weather at sowing time between seasons and within the range of climates [11]. Farmers who plant Kalonji early are concerned about frost, poor emergence and early plant growth while on other hand farmers who plant Kalonji late are concerned the final grain yield and grain moisture (crop maturity) [9]. Nitrogen is vital in crop productivity which plays an important role in accelerating yield and gave optimum economic return and its deficiency will result in low yield and productivity. (Amanullah et al. [12] stated that a split application of $\mathrm{N}$ is suitable to attain optimum crop yield. Timing of $\mathrm{N}$ application is also deliberated as the best managing strategy and is very crucial for crop production [13].
The crop is recognized as a potential component in crop diversification in recent years. The present experiment was aimed to study the sowing time and nitrogen application methods impact on production traits of Kalonji under agro-climatic conditions of Haripur.

\section{Materials and methods}

Site description

The present experiment was conducted during rabi seasons of 2016-17 at Agricultural Research Farm University of Haripur, KPK. The farm is situated in district Haripur with $33^{\circ} 44^{\prime} \mathrm{N}$ latitude, $72^{\circ} 35^{\prime} \mathrm{E}$ longitude and altitude of $610 \mathrm{~m}$ from the mean sea level. Prior to preparatory cultivation of the experimental site, soil samples from 0 to $15 \mathrm{~cm}$ depth were collected at random and composited soil samples was prepared. These samples were analyzed for different physicochemical properties of soil by following the standard methods (Table 1). Rainfall and temperature data were collected and are summarized in (Figure 1). In addition to rainfall, the crop water requirement was fulfilled by supplying water as surface irrigation when required. The results of the soil analysis indicated that the experimental soil belonged to the textural class of silty clay loam, slightly alkaline in reaction, low in available organic carbon and nitrogen, medium in phosphorous and adequate in available potassium.

Table 1. Soil physiochemical analysis

\begin{tabular}{|c|c|c|c|c|c|c|c|c|c|c|}
\hline $\begin{array}{c}\text { Soil } \\
\text { texture }\end{array}$ & $\begin{array}{c}\text { PH } \\
\text { value }\end{array}$ & $\mathbf{E c}$ & $\begin{array}{c}\text { Organic } \\
\text { matter }\end{array}$ & $\begin{array}{c}\mathbf{N} \\
(\%)\end{array}$ & $\mathbf{P}(\mathbf{p p m})$ & $\mathbf{K}(\mathbf{p p m})$ & $\mathbf{C a}+$ & $\mathbf{M g}+$ & $\mathbf{H c o 3}$ & $\mathbf{C l}$ \\
\hline $\begin{array}{c}\text { Silty } \\
\text { Clay } \\
\text { loam }\end{array}$ & 7.85 & 1.19 & 0.55 & 0.064 & 8.71 & 74 & 5.25 & 0.75 & 5.8 & 0.12 \\
\hline
\end{tabular}

\section{Experimentation}

The experiment was laid out in randomized complete block design with split plot arrangement having three replicates. The sowing time were allotted as main-plot factor whereas, nitrogen application methods were taken as sub-plot factor. Kalonji variety NARC-1 was used in the experiment. The 
seeds were dibbled at a depth of $1.5 \mathrm{~cm}$ in rows having 12 inches row to row distance. A seed rate of $5 \mathrm{~kg} \mathrm{ha}^{-1}$ was used for sowing the crop. The seeds were covered with good allotted in subplots. The seeds were sown according to the time i.e. on $20^{\text {th }}$ Oct, $30^{\text {th }}$ Oct, $10^{\text {th }}$ Nov, $20^{\text {th }}$ Nov, $30^{\text {th }}$ Nov and $10^{\text {th }}$ of Dec.

The crop was fertilized with nitrogen, phosphorus and potassium at rate of 40-20-20 $\mathrm{kg} \mathrm{ha}{ }^{-1}$ from sources of urea, triple super phosphate (TSP) and muriate of potash (MP) respectively. The full amounts of triple super phosphate and muriate of potash was applied at final land preparation as a basal dose.

For nitrogen application each plot was divided into three sub plots and urea application was as: $\mathbf{N 1}=$ half dose at sowing and remaining after 60 days after sowing as soil applied. $\mathbf{N} 2=$ Half dose at time of sowing and remaining half after 60 days after sowing

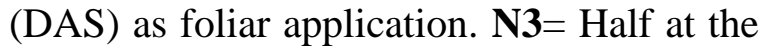
time of sowing and remaining will be applied as 25\% 60 DAS and 25\% 90 DAS as foliar application.

All other cultural practices were kept same. Data on plant height at first flower initiation and maturity, number of days to maturity, yield attributes, yield and quality parameters were recorded. The essential (volatile) oil content in the seed was determined by hydrodistillation according to [14] standard method. The seed oil (fixed oil) content was determined using the Soxhlet extraction according to the official method [14]. The data collected on different parameters was subjected to analysis of variance (ANOVA) technique to observe the difference, between different treatments as well as their interactions. In case where the difference was significant the mean was further assessed for differences through least significant difference (LSD) test. Statistical computer software, Statistix 8.1, was applied for computing both ANOVA and LSD [15].

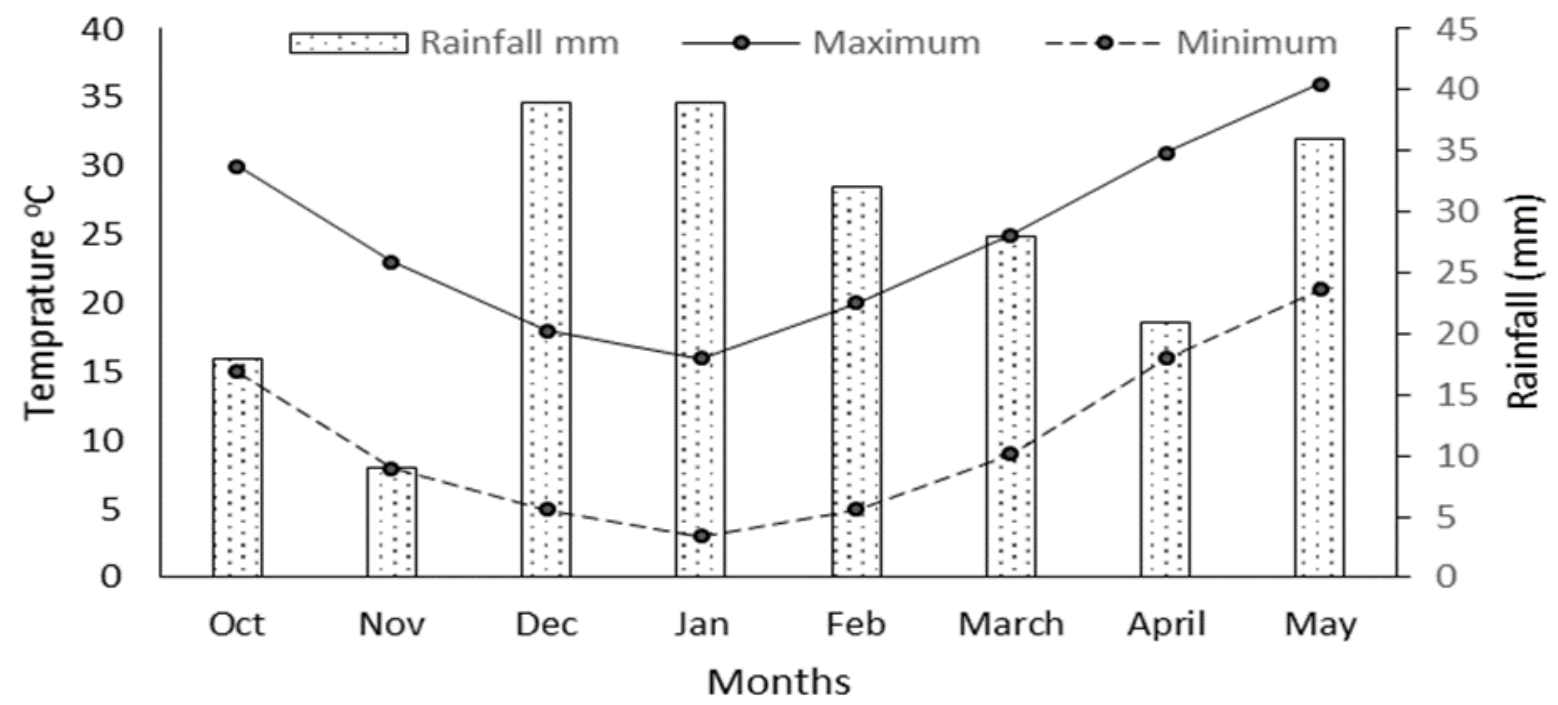

Figure 1. Average monthly meteorological data during crop growth season

\section{Results and discussion}

Plant height at $1^{\text {st }}$ flowering (cm)

Plant height at $1^{\text {st }}$ flowering was significantly affected by sowing time and nitrogen application methods whereas, its interaction were found non-significant (Table 2). Tallest plants at first flowering $(54.5 \mathrm{~cm})$ was observed in crop sown on $30^{\text {th }}$ October followed by $(51.05 \mathrm{~cm})$ crop sown on $20^{\text {th }}$ October however, shorter plants height at $1^{\text {st }}$ 
flowering $(29.67 \mathrm{~cm})$ was recorded in crop sown on $10^{\text {th }}$ of December. Regarding nitrogen application methods tallest plants $(44.87 \mathrm{~cm})$ were recorded when nitrogen was applied as $50 \%$ nitrogen during sowing, 25\% 60 DAS as foliar application and remaining $25 \% 90$ DAS as foliar, while minimum plant height at $1^{\text {st }}$ flowering $(42.13 \mathrm{~cm})$ was recorded when nitrogen was applied as $50 \%$ nitrogen during sowing and remaining $50 \%$ nitrogen 60 days after sowing as foliar application (Table 3). The significant decrease in plant height in the delayed sowings treatments could be associated with lower minimum temperatures which discouraged active early growth and assimilate-building. Thus, the plants did not have adequate opportunity for photosynthesis and their height decreased. [16] Similar observations were reported by previous study on Kalonji. [18] Mentioned that foliar spraying of urea wasn't superior to soil application however, combination of soil and foliar application treatments showed positive responses and these treatments needs further examination, and this means that the nitrogen applied through foliar feeding without any quantities of soil-N applied are not fairly enough to face the necessities of plants.

\section{Plant height at maturity $(\mathbf{c m})$}

Plant height at maturity was significantly affected by sowing time and nitrogen application methods whereas, its interaction were found non-significant (Table 2). Tallest plants at maturity $(62.23 \mathrm{~cm})$ were recorded with crop sown on $30^{\text {th }}$ October, followed by $(56.49 \mathrm{~cm})$ crop sown on $20^{\text {th }}$ October, whereas smallest plants at maturity $(37.48 \mathrm{~cm})$ were recorded in crop sown on $10^{\text {th }} \quad$ December. Regarding nitrogen application methods tallest plants at maturity $(51.73 \mathrm{~cm})$ were observed when nitrogen was applied as $50 \%$ during sowing and remaining $25 \% 60$ DAS and 25\% 90 DAS as foliar application while smallest plants at maturity $(48.82 \mathrm{~cm})$ were in nitrogen application method of $50 \%$ nitrogen during sowing and remaining 50\% 60 DAS as foliar applied (Table 3). Decrease in plant height in late sowing was due to shorter growing period. Early sown crop may have enjoyed the better environmental conditions especially the temperature and solar radiation which resulted in higher plant height. Also, it seems that the decrease in height at the last sowing date was brought about not only by shorter growing period, but also by shorter day length which accelerated flowering and thus, stunted the growth of main stem. Method of nitrogen application played an important role in plant height. Since the recovery of nitrogen as $50 \%$ during sowing and remaining half as foliar application remains higher. These results are in line with the findings of [17, $18]$.

Table 2. Analysis of variance results (Mean square) for different traits of Kalonji under various sowing time and different nitrogen application methods

\begin{tabular}{|c|c|c|c|c|c|c|c|c|c|c|}
\hline Source & $\begin{array}{c}\text { D } \\
\text { f }\end{array}$ & $\begin{array}{c}\text { Plant } \\
\text { height at } \\
\text { 1st } \\
\text { flowering }\end{array}$ & $\begin{array}{c}\text { Plant } \\
\text { height } \\
\text { maturity }\end{array}$ & $\begin{array}{c}\text { Days to } \\
\text { maturity }\end{array}$ & $\begin{array}{c}\text { Capsules } \\
\text { plant }\end{array}$ & $\begin{array}{c}\text { Seeds } \\
\text { capsule-1 }\end{array}$ & $\begin{array}{c}\text { 1000- } \\
\text { grain } \\
\text { weight }\end{array}$ & $\begin{array}{c}\text { Grain } \\
\text { yield }\end{array}$ & $\begin{array}{c}\text { fixed } \\
\text { oil } \\
\text { content }\end{array}$ & $\begin{array}{c}\text { Essential } \\
\text { oil } \\
\text { content }\end{array}$ \\
\hline R & 2 & 9.25 & 13.64 & 2.07 & 43.12 & 140.18 & 0.0051 & 43141 & 0.171 & 0.00007 \\
\hline ST & 5 & 758.106 & 717.86 & 2151.81 & 139.21 & 3163.75 & 2.824 & 894097 & 28.268 & 0.0016 \\
\hline Error r*SD & 10 & 9.84 & 9.75 & 5.3 & 21.56 & 104.03 & 0.053 & 70277 & 0.459 & 0.00025 \\
\hline NM & 2 & 33.98 & 39.904 & 25.41 & 24.44 & 901.94 & 0.312 & 355252 & 3.221 & 0.00001 \\
\hline SD*NM & 10 & 6.51 & 6.57 & 15.36 & 44.63 & 69.59 & 0.143 & 69303 & 0.732 & 0.00006 \\
\hline Error & 24 & 5.72 & 4.39 & 3.04 & 4.02 & 68.04 & 0.0876 & 51830 & 0.387 & 0.00012 \\
\hline CV \% & & 5.5 & 4.18 & 0.97 & 6.05 & 10.46 & 12.81 & 23 & 1.8 & 3.08 \\
\hline Mean & & 43.54 & 50.106 & 180.48 & 33.16 & 78.88 & 2.31 & 990 & 34.51 & 0.35 \\
\hline
\end{tabular}

Significant at 0.05 level 


\section{Number of days to maturity}

The number of days to maturity was significantly influenced by time of sowing, nitrogen application methods and their interaction (Table 2). Significantly highest number of days to maturity were taken by crop sown on $20^{\text {th }}$ October (200.56 days), followed by (191.11 days) crop sown on $30^{\text {th }}$ October while least number of days (158.00 days) to maturity was observed in crop sown on $10^{\text {th }}$ December. Regarding nitrogen application methods significantly higher number of days to maturity (181.22 days) was recorded when nitrogen was applied as $50 \%$ nitrogen during sowing $+50 \% 60$ DAS as foliar application while minimum number of days to maturity (179.11 days) were

Table 3. Mean of plant height, days to maturity, number of capsules plant ${ }^{-1}$ and no of seeds capsule $^{-1}$ of Kalonji as affected by various sowing time and nitrogen application methods

\begin{tabular}{|c|c|c|c|c|c|}
\hline & $\begin{array}{c}\text { Plant height at } \\
\text { first flowering }\end{array}$ & $\begin{array}{c}\text { Plant Height(cm) } \\
\text { at maturity }\end{array}$ & $\begin{array}{c}\text { Days to } \\
\text { maturity }\end{array}$ & $\begin{array}{c}\text { No of Capsules } \\
\text { plant }^{-1}\end{array}$ & $\begin{array}{c}\text { No of seeds } \\
\text { capsule }^{-1}\end{array}$ \\
\hline \multicolumn{7}{|c|}{ Sowing time } \\
\hline 20-Oct & $51.05 \mathrm{~b}$ & $56.49 \mathrm{~b}$ & $200.56 \mathrm{a}$ & $31.34 \mathrm{bc}$ & $91.6 \mathrm{~b}$ \\
\hline 30-Oct & $54.5 \mathrm{a}$ & $62.23 \mathrm{a}$ & $192.11 \mathrm{~b}$ & $35.94 \mathrm{ab}$ & $81.01 \mathrm{bc}$ \\
\hline $\mathbf{1 0 - N o v}$ & $46.53 \mathrm{c}$ & $52.37 \mathrm{c}$ & $184.89 \mathrm{c}$ & $39.38 \mathrm{a}$ & $106.58 \mathrm{a}$ \\
\hline 20-Nov & $42.45 \mathrm{~d}$ & $48.57 \mathrm{~d}$ & $178.11 \mathrm{~d}$ & $32.99 \mathrm{bc}$ & $74.15 \mathrm{~cd}$ \\
\hline 30-Nov & $37.04 \mathrm{e}$ & $43.47 \mathrm{e}$ & $169.22 \mathrm{e}$ & $28.47 \mathrm{c}$ & $53.38 \mathrm{e}$ \\
\hline 10-Dec & $29.67 \mathrm{f}$ & $37.48 \mathrm{f}$ & $158.00 \mathrm{f}$ & $30.81 \mathrm{c}$ & $66.57 \mathrm{~d}$ \\
\hline LSD & $\mathbf{3 . 2 9}$ & $\mathbf{3 . 2 8}$ & $\mathbf{2 . 4 1}$ & $\mathbf{4 . 8 7}$ & $\mathbf{1 0 . 7 1}$ \\
\hline \multicolumn{7}{|c|}{ Nitrogen application methods } \\
\hline NM1 & $43.62 \mathrm{ab}$ & $49.75 \mathrm{a}$ & $179.11 \mathrm{~b}$ & $31.81 \mathrm{~b}$ & $71.87 \mathrm{c}$ \\
\hline NM2 & $42.13 \mathrm{~b}$ & $48.82 \mathrm{~b}$ & $181.22 \mathrm{a}$ & $33.78 \mathrm{a}$ & $78.73 \mathrm{~b}$ \\
\hline NM3 & $44.87 \mathrm{a}$ & $51.73 \mathrm{a}$ & $181.11 \mathrm{~b}$ & $33.88 \mathrm{a}$ & $86.03 \mathrm{a}$ \\
\hline LSD & $\mathbf{1 . 6 4}$ & $\mathbf{1 . 4 4}$ & $\mathbf{1 . 1 9}$ & $\mathbf{1 . 3 8}$ & $\mathbf{5 . 6 7}$ \\
\hline SD & N & Ns & $*$ & $*$ & Ns \\
\hline
\end{tabular}

Note: NM1: 50\% during sowing and remaining 50\% 60 DAS as soil applied, NM2: 50\% during sowing and remaining 50\% 60 DAS as foliar application and NM3: 50\% during sowing and remaining 25\% 60 DAS and 25\% 90 DAS as foliar application, NS: non-significant results

\section{Number of capsules plant ${ }^{-1}$}

The number of capsules plant ${ }^{-1}$ was significantly influenced by sowing time, nitrogen application method and their interaction (Table 2). Highest capsules plant ${ }^{-}$ 1 (39.85) was in crop sown on $10^{\text {th }}$ of November followed by (35.94) crop sown on $30^{\text {th }}$ October, while lowest number of capsules plant ${ }^{-1}$ (28.47) was recorded in crop sown on $30^{\text {th }}$ November. Among nitrogen recorded when nitrogen was applied as 50\% nitrogen during sowing and remaining 50\% 60 DAS as soil applied (Table 3). Concerning interaction, highest number of days to physiological maturity (204 days) was taken was applied as 50\% during sowing and remaining 25\% 60 DAS and 25\% 90 DAS as foliar application respectively (Figure 2). This can be attributed to the plasticity of the crop to adjust to prevailing weather and competition for resources by reprogramming the different phonological stages, and also availability of essential nutrient like nitrogen at crucial stages also affected crops maturity. These results are in agreement with those of $[16,19]$ when crop was sown on $20^{\text {th }}$ Oct and nitrogen 
number of capsules plant $^{-1}$ (44.3) was obtained in the crop sown on $10^{\text {th }}$ November applied with nitrogen as 50\% during sowing as soil applied and remaining $50 \%$ as foliar application 60 DAS (Figure 3). The significantly higher values for number of capsules plant $^{-1}$ in the narrow margin of sowing time was due to the higher number of branches, dry matter accumulation and growth rates at different stages of plant growth. Delay in planting caused severe reduction in the number of capsules per plant and hence early sowing was reported to be critical in Kalonji. Application of nitrogen at critical stages of plant growth significantly influenced number of capsules plant ${ }^{-1}$ which later on has a significant impact on yield. These results are in line with the findings of $[19,20]$.

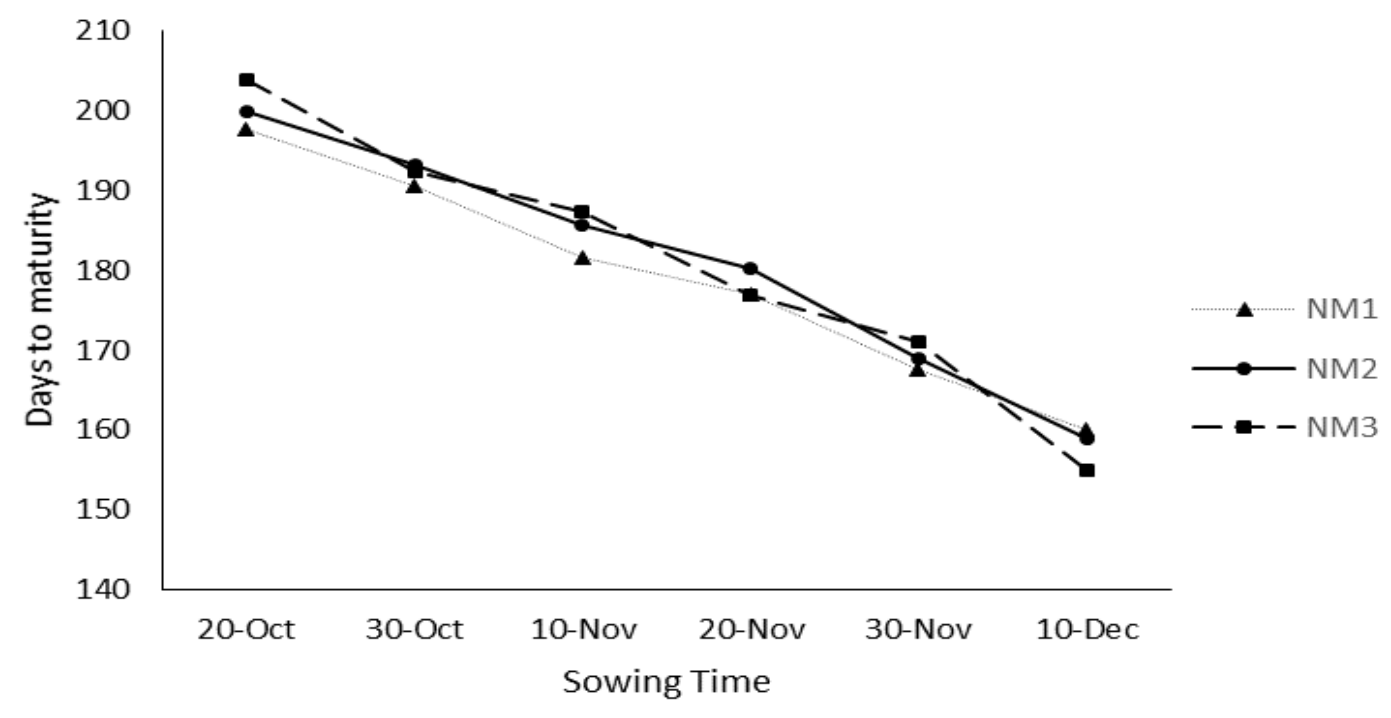

Figure 2. Days to maturity as affected by interaction of sowing time and nitrogen application methods

\section{Number of seeds per capsule}

The number of seeds per capsule was significantly influenced by sowing time and nitrogen application methods, but their interaction was not significant (Table 2). Maximum number of seeds capsule $^{-1}$ (106.58) was recorded in crop sown on $10^{\text {th }}$ of November followed by (91.6) crop sown on $20^{\text {th }}$ October, while minimum number of seeds capsule ${ }^{-1}$ (53.38) was recorded in crop sown on $30^{\text {th }}$ November. Regarding nitrogen application methods highest number of seeds capsules $^{-1}$ (80.03) was obtained when nitrogen was applied as $50 \%$ during sowing as soil applied and remaining 25\% 60 DAS and $25 \% 90$ DAS as foliar application, whereas minimum number of seeds capsule ${ }^{-1}$ (71.87) was recorded during nitrogen application method of 50\% nitrogen during sowing and remaining half $60 \mathrm{DAS}$ as soil applied (Table 3). Reduced growth and yield in delayed sowing was attributable to changes in the radiation and temperature which are unfavorable to the crop. The advantage of suitable season and time of sowing is irreplaceable with any other agronomic management. The advantage of 
suitable time of sowing was reported in different farming situations $[21,22]$.

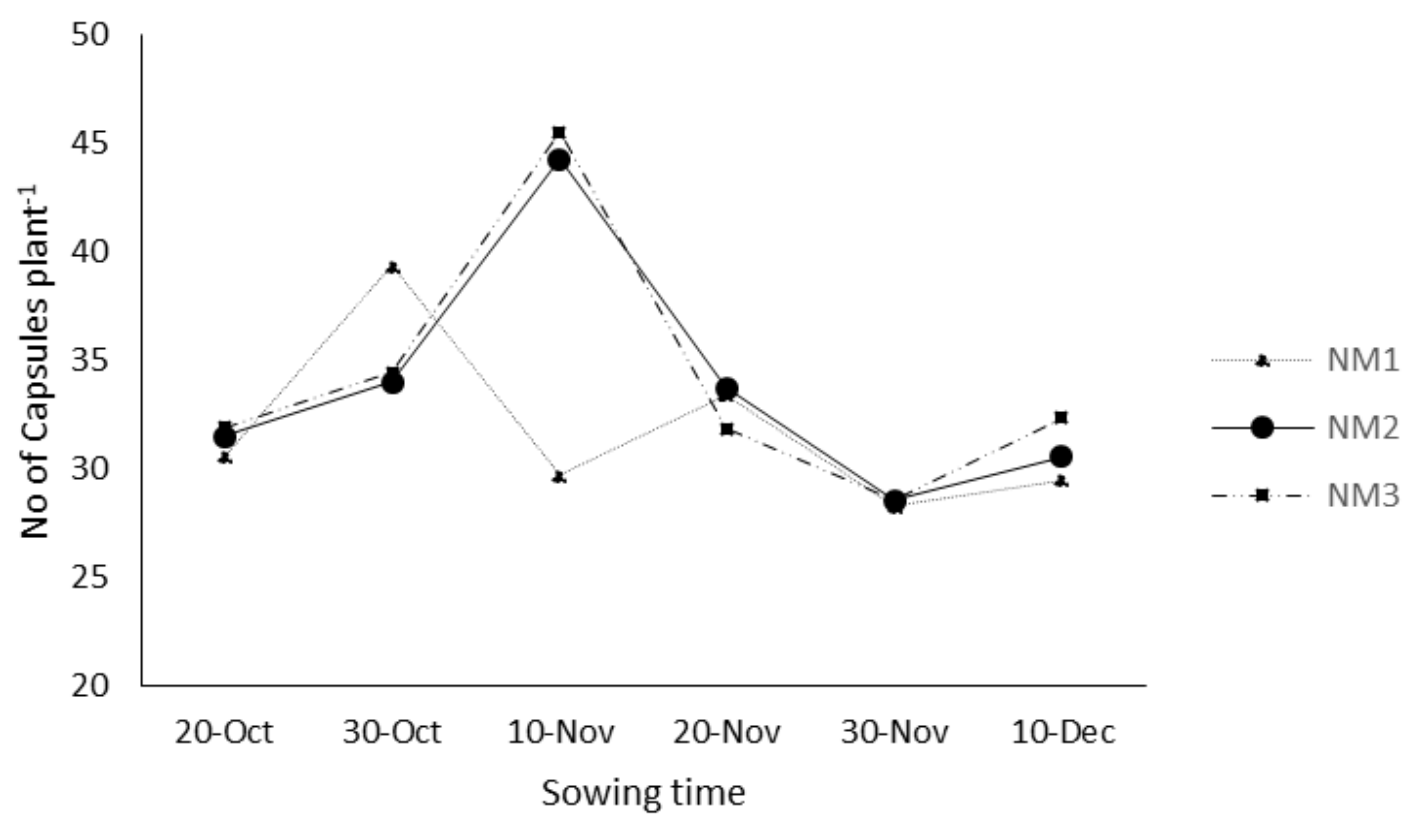

Figure 3. Number of capsules plant ${ }^{-1}$ as affected by interaction of sowing time and nitrogen application methods

\section{0-grains weight $(\mathrm{g})$}

1000-grains weight was significantly influenced by the time of sowing and nitrogen application methods, but not by their interaction during the study (Table 2). Highest 1000-grains weight (2.84 g) was recorded in the crop sown on $10^{\text {th }}$ of November followed by $(2.49 \mathrm{~g})$ crop sown on $20^{\text {th }}$ November while lowest 1000-grain weight $(1.55 \mathrm{~g})$ was recoded in crop sown on $30^{\text {th }}$ November. Among nitrogen application methods, significantly higher 1000-grains weight $(2.38 \mathrm{~g})$ was observed with nitrogen application method of $50 \%$ during sowing as soil applied and remaining 25\% 60 DAS and $25 \% 90$ DAS as foliar application while lowest 1000-grains weight $(2.15 \mathrm{~g})$ was recorded when nitrogen was applied as $50 \%$ during sowing and remaining 50\% 60 DAS as soil applied (Table 4). Crop sown in early November had produced bold and plump grains, it may be due to the reason that because it had prolong period for growth and development and grain filling period and faster growth of late sown crop has affected the grain size and produced lighter grains. 1000-grain weight resulting from delayed sowing was probably due to the decrease in translocation of photosynthates to the ripening grain. This may be due to the provision of $\mathrm{N}$ through urea spray at later growth stages which might have enhanced accumulation of assimilates in the grains and thus resulting in heavier grains of Kalonji. Similar observations were observed by $[16$, 22]. 
Table 4. Mean of 1000-grain weight $(\mathrm{g})$, grain yield $(\mathrm{kg} / \mathrm{ha})$, essential oil content $(\%)$ and fixed oil content $(\%)$ of Kalonji as affected by various sowing dates and nitrogen application methods

\begin{tabular}{|c|c|c|c|c|}
\hline & $\begin{array}{c}\text { 1000-grain weight } \\
\text { (grams) }\end{array}$ & seed yield (kg/ha) & $\begin{array}{l}\text { Essential oil } \\
\text { content }(\%)\end{array}$ & $\begin{array}{c}\text { Fixed oil content } \\
(\%)\end{array}$ \\
\hline \multicolumn{5}{|c|}{ Sowing time } \\
\hline 20-Oct & $2.65 \mathrm{ab}$ & $1169.6 \mathrm{~b}$ & $0.34 \mathrm{c}$ & $35.70 \mathrm{~b}$ \\
\hline 30-Oct & $2.65 \mathrm{ab}$ & $1002.2 \mathrm{bc}$ & $0.35 \mathrm{bc}$ & $35.06 \mathrm{bc}$ \\
\hline 10-Nov & $2.84 \mathrm{a}$ & $1480.0 \mathrm{a}$ & $0.37 \mathrm{a}$ & $36.93 \mathrm{a}$ \\
\hline 20-Nov & $2.49 \mathrm{a}$ & $952.6 \mathrm{bc}$ & $0.36 \mathrm{ab}$ & $34.41 \mathrm{c}$ \\
\hline 30-Nov & $1.55 \mathrm{c}$ & $754.6 \mathrm{~cd}$ & $0.35 \mathrm{bc}$ & $32.57 \mathrm{~d}$ \\
\hline 10-Dec & $1.65 \mathrm{c}$ & $580.7 \mathrm{~d}$ & $0.33 \mathrm{c}$ & $32.42 \mathrm{~d}$ \\
\hline LSD & 0.24 & 278.45 & 0.016 & 0.71 \\
\hline \multicolumn{5}{|c|}{ Nitrogen application methods } \\
\hline NM1 & $2.15 \mathrm{~b}$ & $899.6 \mathrm{~b}$ & $0.353^{\mathrm{NS}}$ & $34.66 \mathrm{a}$ \\
\hline NM2 & $2.38 \mathrm{a}$ & $918.5 \mathrm{~b}$ & 0.353 & $34.04 \mathrm{~b}$ \\
\hline NM3 & $2.38 \mathrm{a}$ & $1151.9 \mathrm{a}$ & 0.352 & $34.84 \mathrm{a}$ \\
\hline $\mathbf{L S D}(0.05)$ & 0.2 & 156.62 & Ns & 0.42 \\
\hline SD $\times \mathbf{N M}$ & Ns & Ns & Ns & Ns \\
\hline
\end{tabular}

\section{Seed yield (kg/ha)}

Seed yield (kg/ha) was significantly influenced by sowing time and nitrogen application methods, but their interaction was non-significant during the study (Table 2). Highest seed yield was recorded with the crop sown on $10^{\text {th }}$ of November $(1480 \mathrm{~kg} / \mathrm{ha})$ followed by crop sown on $20^{\text {th }}$ October $(1169.6 \mathrm{~kg} / \mathrm{ha})$ whereas, lowest seed yield was observed when crop was sown on $10^{\text {th }}$ December $(580.7 \mathrm{~kg} / \mathrm{ha})$. Regarding nitrogen application methods, highest seed yield $(1151.9 \mathrm{~kg} / \mathrm{ha})$ was recorded when nitrogen was applied as $50 \%$ during sowing as soil applied and remaining 25\% 60 DAS and 25\% 90 DAS as foliar application, whereas lowest grain yield $(899.6 \mathrm{~kg} / \mathrm{ha})$ was recorded when nitrogen was applied as 50\% during sowing and remaining 50\% 60 DAS as soil applied (Table 4). The mid sown crop has higher grain yield because drop of temperature and unfavorable conditions for growth at late sowing had decreased the grain yield. Results obtained from the study were comparable with $[23,24]$ findings that delayed sowing results in reduced vegetative growth leading to reduced number of capsules per plant and seed yield $(\mathrm{kg} / \mathrm{ha})$.
Fixed oil content \% ( $\left.\mathrm{vw}^{-1}\right)$

The fixed oil content of Kalonji seed $\left(\% v^{-1}\right)$ was significantly influenced by sowing time and nitrogen application methods, but their interaction was non-significant during the study (Table 2). Optimum fixed oil content (36.93\%) was recorded with the crop sown on $10^{\text {th }}$ November followed by crop sown on $20^{\text {th }}$ October $(35.7 \%)$, while lowest fixed oil content $(32.42 \%)$ was recorded in crop sown on $10^{\text {th }}$ December. Concerning nitrogen methods, Fixed oil content recorded with nitrogen application method of 50\% during sowing as soil applied and remaining 25\% 60 DAS and 25\% 90 DAS as foliar application was on par and significantly superior over others $(34.84 \%)$ during the study while nitrogen application method of $50 \%$ during sowing and remaining 50\% 60 DAS as foliar application shows lowest fixed oil content (34.04\%) (Table 4). The higher fixed oil content with early sowing may be due to improved dry matter production and enhanced source capacity which might have improved the translocation of photo-assimilates to sink, thus promoting the biosynthesis of oil. These results are in accordance with those of [19, 21]. 


\section{Essential oil content}

The essential oil content of the Kalonji seeds $\left(\% \mathrm{v} \mathrm{w}^{-1}\right)$ was significantly influenced by time of sowing alone during the study. Significantly higher essential oil content was recorded with the crop sown on $10^{\text {th }}$ November followed by crop sown on $20^{\text {th }}$ November $(0.37$ and $0.36 \%$ respectively), whereas, minimum essential oil content $(0.33$ $\% \mathrm{vw}^{-1}$ ) was recorded in crop sown on $10^{\text {th }}$ of December (table 4). Environmental factors such as light, temperature, and moisture status can greatly influence the emission of volatiles and the yield and composition of essential oils [25]. The differences in the essential oil content due to the time of sowing may be due to the differences in light, temperature and relative humidity which prevailed during different crop phonological stages in each sowing [16].

\section{Conclusion}

Based on present research it is concluded that sowing time of Kalonji in agro-climatic conditions was critical to increased seed yield possibly due to higher number of Capsules per plant, plant height, fixed oil content and essential oil content. Nitrogen is very much important for increasing yield. Right application time of $\mathrm{N}$ improved nitrogen use efficiency of Kalonji. Split application of nitrogen is suitable to attain optimum Kalonji yield and quality. It was concluded from the research that morphology, yield and quality of Kalonji perform better when crop was sown at $10^{\text {th }}$ of November, and nitrogen was applied as $50 \%$ during sowing and remaining 25\% 60 DAS and 25\% 90 DAS as foliar application.

\section{Authors' contributions}

Design the experiment: A Mehmood \& K Naveed, Data collection, analysis and interpretation: A Mehmood, K Azeem \& K Naveed, Technical help and revision of the manuscript: A Khan \& SM Khan, Downloaded the related review: N Ali, Wrote the paper: A Mehmood.

\section{References}

1. Saul H, Madella M, Fischer A, Glykou A, Hartz S \& Craig OE (2013). Phytoliths in pottery reveal the use of spice in European prehistoric cuisine. PLoS One 8(8): e70583.

2. Naz H (2011). Nigella sativa: the miraculous herb. Pak J Biochem Mol Biol 44(1): 44-48.

3. Schleicher P \& Saleh M (2000). Black cumin: the magical Egyptian herb for allergies, asthma, and immune disorders: Inner Traditions/Bear \& Co.

4. Ramadan MF (2007). Nutritional value, functional properties and nutraceutical applications of black cumin (Nigella sativa L.): an overview. International J of Food Sci \& Technol 42(10): 1208-1218.

5. Jansen PCM 1(981). Spices, condiments and medicinal plants in Ethiopia, their taxonomy and agricultural significance: [sn].

6. Zohary D, Hopf M \& Weiss E (2012). Domestication of Plants in the Old World: The origin and spread of domesticated plants in Southwest Asia, Europe, and the Mediterranean Basin, Oxford University Press on Demand.

7. Bukhari A (1985). Sahih-ul-Bukhari. Federal Ministry of Education, Govt. of Pakistan Islamabad.

8. AlAttas SA, Fat'heya MZ \& Turkistany SA (2016). Nigella sativa and its active constituent thymoquinone in oral health. Saudi Medical J 37(3): 235.

9. Giridhar K, Reddy G, Surya Kumari S \& Naram Naidu L (2015). Nigella: A Seed Spice of Blessing. Spice India.

10. Ahmad Z, Ghafoor A \& Aslam, M (2004). Nigella sativa-A potential commodity in crop diversification traditionally used in health care. Project on Introduction of Medicinal herb and species as crop. Ministry of Food, Agriculture and Livestock Pakistan 6-10. 
11. Aziz A, Rehman HU \& Khan N (2007). Maize cultivar response to population density and planting date for grain and biomass yield. Sarhad J of Agri 23: 25.

12. Amanullah, Khattak RA \& Khalil SK (2009). Plant density and nitrogen effects on maize phenology and grain yield. $J$ of Plant Nutrition 32(2): 246-260.

13. Walsh OS (2006). Effect of delayed nitrogen fertilization on corn grain yields. Oklahoma State University.

14. AOAC (2000). Official methods of analysis of AOAC International (17th Ed.). Maryland, USA: AOAC.

15. Gomez KA \& Gomez AA (1984). Statistical procedures for agricultural research. John Wiley \& Sons.

16. El-Mekawy MA (2012). Growth and yield of Nigella sativa L. plant influenced by sowing date and irrigation treatments. American-Eurasian J Agric and Environ. Sci 12: 499-505.

17. Shahzad K, Bakht J, Shah WA, Shafi M \& Jabeen N (2002). Yield and yield components of various wheat cultivars as affected by different sowing dates. Asian J Plant Sci 1(5): 522-525.

18. Sharma R, \& Ezekiel R (1993). Influence of time of nitrogen application on number and size of potato (Solanum tuberosum) tubers. Indian soc agronomy Indian agr res inst div agronomy, New Delhi 110012, India 38: 154-156.

19. Talafih, Khaled A., Nasri I. Haddad, Butros I. Hattar \& Kamal Kharallah (2010). Effect of some agricultural practices on the productivity of black cumin (Nigella sativa L.) grown under rainfed semi-arid conditions. J of Agri Sci 3: 4

20. Moghaddam PR, Seyedi SM \& Azad M (2014). Effects of organic, chemical and biological sources of nitrogen on nitrogen use efficiency in black seed (Nigella sativa L.). Iranian $J$ of Medicinal and Aromatic Plants 30(2).

21. D'Antuono LF, Moretti A \& Lovato AF (2002). Seed yield, yield components, oil content and essential oil content and composition of Nigella sativa L. and Nigella damascena L. Industrial Crops and Products 15(1): 59-69.

22. Meena SS, Anwer MM, Mehta RS, Lal G, Kant K, Sharma YK \& Meena SR (2011). Performance of nigella (Nigella sativa L.) as influenced by sowing dates and crop geometry in semi-arid eco-system. Inter $J$ Seed Spices 1(1): 8-12.

23. Ehteramian K (2003). The effects of different levels of nitrogen fertilizer and plant dating on black cumin (Cuminum carvi L.) in Kooshkak region in the Fars province. Master of Science Thesis of Arid Area Management, Shiraz University, Shiraz.

24. Sharratt, BS \& Gesch RW (2004). Water Use and Root Length Density of spp. Influenced by Row Spacing and Sowing Date. Agronomy J 96(5): 1475-1480.

25. Dudareva N, Pichersky E \& Gershenzon J (2004). Biochemistry of plant volatiles. Plant Physiology 135(4): 18931902. 